\title{
ANALISA PENDIDIKAN PESANTREN DAN PERANNYA TERHADAP PENDIDIKAN ISLAM
}

\author{
Fathul Amin \\ STIT Makhdum Ibrahim Tuban \\ email : fathulamin@stitmatuban.ac.id
}

\begin{abstract}
Abstrak
Pesantren adalah lembaga pendidikan yang unik. Bukan hanya karena keberadaannya yang sangat lama, tetapi juga karena budaya, metode, dan jaringan yang diterapkan oleh institusi. Oleh karena itu, banyak penelitian telah dilakukan dari perspektif yang berbeda, terutama dalam hal periodisasi sejarahnya. Namun, penelitian ini tampaknya sangat luas dan dijelaskan secara umum sambil berkorelasi dengan peran dan kemajuannya. Atas dasar ini, laporan penelitian ini akan memeriksa lebih dalam peran pendidikan pesantren dalam konteks pendidikan Islam. Penelitian ini bertujuan mengidentifikasi peran pondok pesantren sebagai Lembaga Pendidikan Islam. Penelitian ini menggunakan pendekatan kualitatif dan metode studi literatur. Berdasarkan hasil penelitian, pesantren sebenarnya menyediakan proses pengajaran, mendidik, mengembangkan, dan menyebarkan agama Islam. Sehubungan dengan tujuan pondok pesantren, pada prinsipnya bertujuan untuk mengembangkan kepribadian Islam, khususnya kepribadian yang lebih menaruh perhatian pada kepercayaan dan kesadaran Allah, karakter mulia, kesalehan, kegunaan dan kesetiaan kepada masyarakat, dan menjadi penjaga. dari semua umat manusia (khadim al-ummah).

Kata kunci : Pendidikan Pesantren, Pendidikan Islam
\end{abstract}

\section{PENDAHULUAN}

Ajaran Islam mewajibkan umatnya untuk melaksanakan Pendidikan, Pendidikan merupakan kebutuhan hidup manusia dalam rangka mencapai kesejahteraan dan kebahagian Dunia Akhirat.( Zuhairini, 1995). Di Indonesia sendiri, pemerintah telah merumuskan tujuan pendidikan untuk mewujudkan pendidikan yang berkualitas, yang tertuang dalam UndangUndang No 20 tahun 2003 tentang sistem pendidikan nasional disana tercantum bahwa tujuan pendidikan nasional ialah Mengembangkan potensi peserta didik agar menjadi manusia yang beriman dan bertakwa kepada Tuhan Yang Maha Esa, berakhlak mulia, sehat, berilmu, cakap, kreatif, mandiri dan menjadi warga negara yang demokratis serta bertanggung jawab.

Dalam mencapai tujuan diatas, pondok pesantren diharuskan siap dalam membina peserta didiknya supaya menjadi lebih baik, menjadi insan rohmatal lil'alamin. Pondok pesantren yang melembaga di masyarakat, merupakan salah satu lembaga pendidikan Islam yang mempunyai tugas penting dalam pendidikan islam untuk mendalami ilmu- ilmu agama Islam sebagai pedoman hidup (tafaqquh fi al-din)

Tadris, Volume 13/ No. 2/ Tahun $2019 \mid 56$ 
Peran Pondok pesantren dalam meningkatkan kualitas sumber daya manusia dianggap penting sama Seperti yang umum diketahui yakni pesantren sebenarnya tidak hanya memberikan pengetahuan dan keterampilan teknis, tetapi yang jauh lebih penting adalah menanamkan nilai-nilai moral dan agama. Filosofi pendidikan pesantren didasarkan atas hubungan yang bermakna antara manusia dengan Allah SWT Hubungan tersebut memiliki makna jika bermuatan atau menghasilkan keindahan dan keagungan. Ibadah yang dijalani oleh semua guru dan santri di pondok pesantren diutamakan dalam hal mencari ilmu, mengelola pelajaran, mengembangkan diri, mengembangkan kegiatan bersama santri dan masyarakat.

Pesantren dipandang sebagai lembaga yang merupakan pusat dari perubahan Masyarakat melalui kegiatan dakwah Islam, namun hal itu harus tercermin dalam perubahan dan pengembangan individu maupun perkembangan kelompok Masyarakat. Sesuai dengan ungkapan Muhtaron, (2002) “Tujuan Pendidikan dalam Pondok Pesantren tidak semata-mata memperkaya pikiran santri dengan teks dan penjelasan yang Islami, tetapi untuk meninggikan moral, melatih dan mempertinggi semangat, menghargai nilai- nilai spiritual dan kemanusiaan, mengerjakan sikap dan tingkah laku yang jujur dan bermoral serta menyiapkan santri untuk hidup sederhana dan bersih hati."

Dalam hal ini Pondok Pesantren memiliki banyak fungsi, diantaranya sebagai lembaga Pendidikan Islam dalam rangka melestarikan dan mengembangkan ajaran Agama Islam, sehingga Pondok Pesantren dikatakan sebagai lembaga syiar Islam. Fungsi Pondok Pesantren yang tidak kalah pentingnya adalah bahwa Pondok Pesantren berfungsi sebagai lembaga pembangunan, pengembangan dan pemberdayaan Masyarakat. Jadi Pesantren sebagai sebuah sistem Pendidikan, telah memberikan kontribusi yang nyata bagi perkembangan Islam. Sebagai institusi keislaman, Pesantren mampu menduduki posisi yang relatif penting dalam Masyarakat, dan mampu bertahan di tengah-tengah gelombang perubahan sampai saat ini. Pendidikan Pondok Pesantren, menyiapkan pribadi muslim yang tangguh, harmonis, mampu mengatur kehidupan pribadinya, mengatasi persoalan-persoalan kebutuhan Hidup serta mampu mengarahkan tujuan hidupnya.

Keberadaan pesantren menjadi data tarik dalam segala aspeknya. Baik kiainya maupun sistem pendidikannya. Itulah yang menjadikan pesantren dan apapun yang dimilikinya sebagai kearifan lokal dan kekayaan intelektual dari nusantara (Abubakar, 2018). Pesantren di era globalisasi ini tampaknya perlu dibaca sebagai kekayaan intelektual nusantara yang mampu memberikan kontribusi terhadap lahirnya khazanah intelektual muslim yang berakhlak mulia serta bertanggung jawab terhadap dirinya maupun masyarakat di 
sekelillingnya (Haryanto, 2017). Oleh karena itu, sangat penting kiranya untuk diadakan sebuah pembahasan sejauh mana peran dan pengaruh pondok pesantren terhadap perkembangan pendidikan islam.

Berdasarkan pada rasional atau konsteks penelitian yang telah diuraikan diatas, maka penelitian ini bertujuan untuk menganalisa pendidikan pesantren sekaligus peranya dalam pendidikan islam. Selanjutnya, penelitian ini diharapkan memberikan manfaat bagi pembaca, baik dari kalangan mahasiswa maupun non mahasiswa, sehingga dapat memahami dunia pendidikan dipesantren serta dapat digunakan sebagai refrensi penyusunan karya ilmiyah, selanjutnya penelitian ini diharapkan dapat memberikan informasi yang akurat tentang pendidikan pesantren dan peranya dalam pendidikan islam, terutama dalam dasar-dasar pendidikan pesantren, tujuan-tujuan pendidikan pesantren, pelaksanaan pendidikan pesantren, prinsip-prinsip pendidikan pesantren, sumber kajian pendidikan pesantren, metode-metode pendidikan pesantren, dan perilaku dan prinsip santri.

\section{METODOLOGI}

Dalam Penelitian ini, pendekatan yang peneliti lakukan adalah penelitian data kualitatif yakni data yang digambarkan dengan kalimat, dipisah-pisahkan menurut kategori untuk memperoleh kesimpulan. Basrowi dan suwandi (2008) menyatakan bahwa "penelitian kualitatif adalah salah satu metode penelitian yang bertujuan untuk mendapatkan pemahaman tentang kenyataan melalui proses berfikir induktif. Melalui penelitian kualitatif, peneliti dapat mengenali subyek, merasakan apa yang mereka alami dalam kehidupan sehari-hari.

Adapun metode yang peneliti gunakan dalam penelitian ini adalah metode studi literatur. Teknik pengambilan data yang dilakukan peneliti yakni mengumpulkan data dari berbagai sumber pustaka baik dari buku, jurnal, hasil seminar dan diskusi dengan para ahli yang relevan dengan tema penelitian. Setelah data terkumpul, peneliti melakukan analisis data dengan teknik interpretasi data dan peneliti memberikan penjelasan secukupnya ditinjau dari teori yang relevan dengan permasalahan yang dihadapi.

Analisis data adalah proses pengorganisasian dan mengurutkan data ke dalam pola, kategori dan satuan uraian dasar sehingga dapat ditemukan tema dan dapat dirumuskan hipodisertasi kerja seperti yang disarankan oleh data (lexy, 2014). Analisis data dan penafsirannya segera mungkin dilaksanakan jangan sampai data yang ada menjadi tidak terpakai atau lupa memberikan makna dari data tersebut. Dari semua data yang telah terkumpul dari lapangan cukup banyak, untuk itu perlu dilakukan analisis data: pengumpulan 
data (Data Collection), reduksi data (Data Reduction), penyajian data (Data Display) dan penarikan kesimpulan (Conclusion).

\section{HASIL DAN PEMBAHASAN}

\section{Analisa Pendidikan Pesantren}

Tujuan pendidikan di pesantren adalah pada pengamalan terhadap ilmu yang telah diperoleh yang disebut dengan ilmu bermanfaat (ilm nāfi). Ini menjadi keunggulan tersendiri pendidikan pesantren, yakni menggabungkan kecerdasan intelektual, emosional dan spiritual yang muaranya dapat membina karakter seseorang (Tamin, 2015).

Pendidikan Pesantren merupakan salah satu Pendidikan di Indonesia yang keberhasilan dan keberadaannya tidak diragukan lagi. Sebuah pesantren biasanya di jalankan oleh seorang kyai yang dibantu oleh sejumlah santri senior atau anggota keluarga yang lain. Pesantren adalah bagian penting kehidupan kyai karena ia merupakan tempat dimana ia mengembangkan ajaran dan pengaruhnya melalui pengajaran (Turmudi, 2003). Untuk menjalankan aktivitasnya sebagai Lembaga pendidikan, Pondok Pesantren tentunya memiliki dasar-dasar pendidikan. Dasar-dasar pendidikan pesantren menurut Tauhid (1990) ada 3, yaitu :

Pertama, Iman (Iman ini dijabarkan dalam bentuk Rukun Iman), Iman merupakan sesuatu yang sangat penting bagi kehidupan manusia. Hanya dengan Iman seseorang bisa meraih kebahagiaan dalam hidup di Dunia sampai Akhirat. Begitu pentingnya Iman bagi seseorang, maka sudah seharusnya bila pendidikan Islam menetapkan Iman sebagai dasar dari sebuah pendidikan.

Kedua, Islam (Islam ini dijabarkan dalam Rukun Islam) Islam adalah sebuah Agama kenabian etis. yang ajarannya bersumber pada Al-Qur'an dan Sunah Rasulullah. Islam secara khusus dibahas dalam Ilmu fiqih, pembicaraan dalam Ilmu fiqih berfokus pada hukum atau aturanaturan, yang fungsinya untuk mengatur kehidupan manusia di Dunia, untuk berhubungan dengan Allah, sesama manusia dan makhluk-makhluk yamg lain agar terjadi keserasian dan keseimbangan.

Ketiga, Ihsan (Ihsan ini dijabarkan dalam bentuk mendekatkan diri kepada Allah SWT) Dalam kehidupan disadari atau tidak, diakui atau tidak, sesungguhnya kita bergantung sepenuhnya kepada kehendak Allah SWT. Maka dalam Islam, Ihsan sangatlah penting. Dengan mendekatkan diri kepada Allah akan lahir manusia-manusia yang bertaqwa, giat beribadah dan mencurahkan segenap aktivitasnya untuk mencari ridha Allah SWT 
Asal usul pesantren ada dua pendapat. Pertama, kelompok ini berpendapat bahwa pesantren merupakan hasil kreasi sejarah anak bangsa setelah mengalami persentuhan budaya dengan budaya pra islam. Kedua, kelompok yang berpendapat bahwa pesantren diadopsi dari lembaga pendidikan Islam Timur-Tengah.

Kurikulum yang digunakan adalah kurikulum pendidikan islam dengan mata pelajaran agama (fiqih, aqaid dan tasawuf), nahwu-sharaf, keagamaan (sesuatu yang lebih mengenai semangat dan ras serta rasa agama) dan lain sebagainya. sementara pengetahuan umum hanya sekedar memenuhi persyaratan pemerintah, system pengajaran intelektualisme (pada ilmu fiqh, aqaid dan nahwu sharaf) dan verbalisme (kuatnya sistem hafalan ditambah kurangnya mata pelajaran yang betul-betul rasionalistik seperti ilmu hitung, ilmu alam maupun ilmu pasti lainnya).

Selain memiliki dasar-dasar pendidikan, Pesantren juga memiliki tujuan-tujuan, Menurut Dhofier (1994), tujuan Pesantren adalah : Tidak hanya untuk memperkaya pemikiran murid dengan penjelasan penjelasan, tetapi untuk meninggikan moral dan melatih semangat dalam nilai-nilai spiritual dan kemanusiaan, mengajarkan sikap dan tingkah laku yang jujur serta menyiapkan para murid untuk hidup sederhana dalam kehidupan sehari- hari.

Setiap murid diajarkan agar menerima etik Agama, diatas etik-etik yang lain. Tujuan Pendidikan Pesantren bukanlah untuk mengejar kepentingan kekuasaan, uang dan keagungan duniawi tetapi ditanamkan kepada mereka bahwa "Belajar adalah semata- mata kewajiban dalam pengabdian kepada Tuhan”. Sesuai dengan dasar pendidikan Islam, maka tujuan Pendidikan Pondok Pesantren dapat diuraikan menjadi 2 (dua) hal : (1) Menjadi manusia pengabdi Allah SWT yang beriman dan bertaqwa, menjadi pelaksana dan pendukung ajaran Islam secara menyeluruh. (2) Menjadi manusia pengabdi Allah SWT yang berperan sebagai Immamul Muttaqiin, Pemimpin dan penyebar Agama Islam di Masyarakat.

Berikutnya, pendidikan pesantren dalam melaksanakan pendidikan dan pembelajaranya berpegang teguh dengan Prinsip-prinsip Pesantren, Menurut Mastuhu (1994) yang dikutip oleh Mujahidin, menjelaskan bahwa prinsip-prinsip pendidikan pesantren meliputi beberapa prinsip di antaranya:

Pertama, Prinsip Theosentrik, Yaitu pandangan yang menyatakan bahwa semua kejadian berasal, berproses dan kembali kepada kebenaran Tuhan (Mujahidin, 2004). Sehingga aktivitas pendidikan dipandang sebagai ibadah serta mengutamakan sikap dan perilku kepada kehidupan Ukhrowi. Implementasi dari pandangan ini adalah bahwa semua kegiatan di Pesantren senantiasa diwarnai dengan nilai-nilai yang sakral. Kegiatan pembelajaran tidak hanya dipandang sebagai proses tetapi juga sebagai tujuan hidup. 
Kedua, Prinsip Sukarela dan Mengabdi, Dalam penyelenggaraan pendidikan dan kegiatan pembelajaran yang dilakukan di Pondok Pesantren, semua didasarkan pada prinsip sukarela dan mengabdi (Mujahidin, 2004). kyai mengajarkan santri secara sukarela dan semata-mata mengabdi kepada Allah SWT. Santri juga menghormati kyai dan temanteman secara sukarela juga semata-mata untuk mengabdi kepada Allah SWT. Hal ini mereka lakukan karena mereka yakin bahwa imbalan yang disediakan Allah lebih banyak dan kekal sifatnya bagi orang-orang yang menafkahkan hartanya dijalan Allah. Dalam hal ini ilmu bagi kyai dan santri merupakan harta yang sangat bernilai. Bagi santri, dirinya tidak akan menjadi orang yang berilmu tanpa adanya seorang guru atau kyai. Dan bagi seorang kyai, untuk mengamalkan Ilmu memerlukan santri sebagai penerus dan calon pengganti sang kyai. Jadi prinsip sukarela dan mengabdi ini nerupakan prinsip yang hampir dipakai oleh semua Pesantren baik Pesantren kecil maupun besar.

Ketiga, Prinsip Kearifan, Kearifan dalam kegiatan pembelajaran Pesantren adalah sikap dan perilaku sabar, rendah hati, patuh terhadap ketentuan Agama, mampu memnacapai tujuan tanpa merugikan orang lain dan dapat memberikan manfaat kepada orang lain. Sikap ini muncul karena ilmu yang dicari dipesantren adalah ilmu-ilmu yang mendekatkan diri seorang hamba kepada Tuhannya.

Keempat, Kesederhanaan, Kesederhanaan merupakan nilai yang sangat ditekankan oleh pesantren. Kesederhanaaan disini bukan hanya menyangkut cara berpakaian, tetapi juga meliputi aspek sikap dan perbuatan. Hal ini dipandang sebagai nilai luhur dan menjadi pedoman perilaku sehari-hari bagi seluruh warga Pesantren. Wujud dari kesederhanaan yang muncul biasanya dalam hal berpakaian, bersikap, bertutur kata dan dalam perbuatanperbuatan yang dilakukan. Nilai kesederhanaan ini tidak hanya dilakukan ketika santri dalam keadaan mondok saja, tetapi biasanya akan terbawa sampai kapanpun.

Kelima, Kolektivitas, Kolektivitas atau rasa kebersamaan dikalangan pesantren sangat tinggi sekali. Hal ini karena kondisi psikologis mereka yang terpisah jauh dari keluarganya, sehingga mereka menemukan saudara baru di pesantren. Prinsip ini sangat menonjol dan memang detekankan untuk menghindari rasa individualis. Sikap gotong royong, saling tolong menolong untuk mengatasi hidup jauh dari keluarga. Hal yang sangat kelihatan dari prinsip ini adalah adanya dapur umum, tempat mandi umum dan kamar sederhana yang dihuni oleh banyak santri.

Keenam, Mengatur Kegiatan Bersama, Hampir semua kegiatan pembelajaran dipesantren seperti perpustakaan, keamanan, ibadah, operasi, olahraga dan ketrampilan diatur oleh para santri. Dalam sebuah Pesantren biasanya ada kegiatan inti dan kegiatan ekstra. 
Kegiatan inti meliputi pengajaran Ilmu-ilmu Agama sedangkan kegiatan ekstra meliputi semua kegiatan di luar pendidikan ilmu agama.

Ketujuh, Mandiri, Setiap santri dituntut untuk mandiri sejak pertama kali masuk di Pesantren. Prinsip ini dapat dilihat dari kehidupan para santri dalam merencanakan dan mengatur kebutuhan hidupnya. Mereka bertanggung jawab atas keperluannya sendiri. Misalnya dalam mengatur uang belanja, memasak, mencuci pakaian, mengatur rencana pembelajaran, dan kapan ia akan kembali kerumahnya.

Kedelapan, Pesantren Tempat Mencari Ilmu dan Mengabdi, Pesantren dipandang oleh para pengelola dan santri sebagai tempat untuk mencari ilmu dan mengabdi. Ilmu dipandang sebagai bgian dari agama. Oleh karena itu seorang santri dapat memperoleh ilmu sebagai.

Kesembilan, Mengamalkan Ajaran Agama, Pesantren sangat mementingkan pengamalan Ajaran Agama, terutama yang berkah dari pengabdiannya kepada Kyai berkaitan dengan masalah Ibadah. Oleh karena itu dalam aktivitas seharihari para santri senantiasa memilki perhatian yang serius dalam masalah Ibadah. Seperti tentang tata cara berwudhu, shalat dan sebagainya.

Selanjutnya, pesantren pada dasarnya hanya mengajarkan agama, sedangkan sumber kajian atau mata pelajarannya ialah kitab-kitab dalam bahasa Arab. Kitab yang dikaji di pesantren umumnya kitab-kitab yang ditulis dalam abad pertengahan, yaitu antara abad ke-12 sampai dengan abadke-15 atau lazim disebut dengan "Kitab Kuning" Untuk memperoleh hasil yang maksimal dalam proses pelaksanaan pendidikan dan dimaksudkan agar tercapainya tujuan pendidikan maka pesantren menggunakan Strategi pembelajaran, Diantara strategi di bidang belajar mengajar adalah menggunakan metode- metode. Beberapa metode yang sering dipakai pada sebuah Pesantren adalah:

Metode Sorogan, sorogan ialah suatu metode dimana santri menghadap guru atau kyai seorang demi seorang dengan membawa kitab yang akan dipelajarinya, Menurut Bahril Ghazali bahwa sistem sorogan adalah: "Seorang santri menyodorkan kitab dan membacanya dihadapan Kyai, ketika ada kesalahan maka Kyai langsung membetulkannya”. Sedangkan menurut Dhofier, Sorogan adalah "Sistem seorang murid dimana seorang murid mendatangi kyai dan beliau membaca beberapa baris Qur'an atau Kitab tertentu, dan meterjemahkannya kedalam bahasa jawa dan pada gilirannya murid tersebut mengulangi sepersis mungkin seperti ajaran gurunya”. Metode sorogan adalah metode yang paling sulit sebab memerlukan kesabaran, kerajinan, ketaatan dan kedisiplinan yang tinggi dari pribadi santri.

Wetonan atau Bandongan, Ini merupakan metode utama dalam sebuah pesantren adalah metode kuliah dimana santri mengikuti pelajaran dengan duduk di sekeliling kyai yang 
menerangkan pelajaran. Santri menyimak kitab masing-masing dan mencatat jika perlu (Basri, 2001 dalam Nata, 1996) Dalam sistem ini sekelompok murid (50 sampai 500) mendengarkan seorang guru membaca, menerjemahkan, menerangkan dan mengulas bukubuku Islam dalam bahasa Arab, setiap murid memperhatikan bukunya sendiri dan membuat tentang catatan-catatan tentang kata-kata atau buah pikiran yang sulit”. Ghazali membedakan sistem Wetonan dengan system Bandongan. Menurutnya, Wetonan adalah "Pembelajaran yang dilaksanakan dengan cara Kyai membaca suatu kitab dalam waktu tertentu, santri dengan kitab yang sama mendengarkan dan menyimak bacaan Kyai serta memahaminya".

Musyawarah atau Mudzakarah Yaitu metode untuk mendiskusikan berbagai masalah yang ditemukan pada santri. Metode ini digunakan ketika terjadi suatu masalah, maka untuk mencari jalan keluar dan mensikapi masalah tersebut diadakan musyawarah. Bahkan metode ini juga sering digunakan hanya untuk membahas sebuah kitab.

Hafalan ialah metode dimana santri menghafal teks atau kalimat tertentu dari kitab yang dipelajarinya. Biasanya cara menghafal ini diajarkan dalam bentuk sya'ir atau nazham, Metode ini digunakan untuk menghafal isi kitab yang sedang mereka pelajari. Materi hafalan tidak sama untuk tiap-tiap Pesantren karena sebuah pesantren biasanya memiliki target tertentu dalam mempelajari sebuah kitab.

Lalaran Adalah metode pengulangan materi. Biasanya dilakukan secara mandiri, materi yang di ulang biasanya materi-materi yang dibahas dalam sorogan maupun bandongan.

Metode-metode ini masih berjalan ketat dibeberapa pesantren saat ini, namun banyak juga pesantren yang telah berhasil mengkombinasikan metode pengajarannya dengan metode yang lebih modern dan komprehensif.

Selanjutnya, Menurut Al-Zarnuji dalam karyanya Ta'lim Al-Muta'alim yang dikutip oleh Mujahidin menyebutkan beberapa prinsip yang dianut para santri untuk mencapai tujuan dan cita-citanya antara lain : (1) Memiliki Niat Yang Benar, Niat merupakan prinsip utama dalam kegiatan belajar. Pekerjaan yang sifatnya duniawi dapat memperoleh akibat ukhrowi, dengan adanya niat baik dari pelakunya. Sebaliknya pekerjaan yang sifatnya ukhrowi dapat menjadi pekerjaan yang duniawi karena niat yang buruk dari pelakunya. (2) Memiliki Guru dan Teman Belajar Ilmu, guru dan teman belajar merupakan tiga faktor yang dapat mempengaruhi keberhasilan dalam kegiatan pembelajaran. Seorang murid atau santri akan dapat berhasil jika ia dapat menekuni ilmu yang sesuai dengan karakteristik dan potensi diri yang dimilikinya, dibimbing oleh seorang guru yang 'alim dan dibantu oleh teman belajar yang baik. (3) Menghormati Ilmu dan Pemiliknya, Salah satu penyebab keberhasilan seseorang dalam memperoleh Ilmu adalah karena ia menghormati Ilmu dan pemiliknya. Ungkapan ini 
bermakna bahwa jika seorang Murid/santri menghormati Ilmu yang tengah dipelajari, maka dia tidak akan menyia-nyiakan kesempatan untuk memperoleh Ilmu tersebut. Adapun jika ia menghormati pemilik Ilmu, maka dalam kegiatan pembelajarannya akan tercipta hubungan harmonis antara keduanya, sehingga proses belajar mengajar akan berlangsung secara efektif. (4) Memiliki Ketekunan, Kesungguhan dan Cita-cita yang Kuat, Ketekunan menunjukan kepada kemampuan seorang murid/santri untuk mengikuti proses pembelajaran tanpa rasa putus asa. Kesungguhan adalah sikap sepenuh hati yang dicurahkan oleh seorang Murid/santri dalam proses pembelajaran.

\section{Pesantren Sebagai Lembaga Pendidikan Islam}

Pesantren adalah lembaga pendidikan dan pengajaran agama Islam yang pada umumnya pendidikan dan pengajaran tersebut diberikan secara non klasikal (sistem bandongan dan sorogan) dimana seorang kyai mengajar santri-santri berdasarkan kitab-kitab yang ditulis dalam bahasa Arab oleh ulama-ulama besar sejak abad pertengahan, sedang para santri biasanya tinggal dalam pondok/asrama dalam pesantren tersebut. pondok pesantren hadir dan siap dalam membina peserta didiknya supaya menjadi lebih baik, menjadi insan rohmatal lil'alamin. Pondok pesantren yang melembaga di masyarakat, merupakan salah satu lembaga pendidikan Islam tertua di Indonesia. Awal kehadiran pondok pesantren bersifat tradisional untuk mendalami ilmu-ilmu agama Islam sebagai pedoman hidup (tafaqquh fi aldin) dengan menekankan pentingnya moral dalam bermasyarakat. (mastuhu, 1994).

Engku \& Zubaidah (2014) mencatat pada dasarnya fungsi utama pesantren adalah sebagai lembaga pendidikan islam yang bertujuan mencetak muslim agar memiliki dan menguasai ilmu-ilmu agama secara mendalam serta menghayati dan mengamalkannya dengan ikhlas semata-mata ditujukan untuk pengabdiannya kepada Allah. Pola pendidikan yang diselenggarakan pesantren beragam. Namun demikian, fungsi yang diembannya sama yakni mendidik dan mengajarkan ilmu-ilmu agama Islam sebagai upaya mewujudkan manusia yang Tafaqquh Fiddīn.

Pesantren berhasil membangun imej sebagai lembaga yang secara khusus dan intensif mempelajari agama Islam (tafaqquh fi al-din), Pada abad ke-18, nama pesantren sebagai lembaga pendidikan rakyat menjadi begitu berbobot, terutama berkenaan dengan perannya dalam menyebarkan ajaran Islam. Pada masa itu berdirinya pesantren senantiasa ditandai dengan "perang nilai" antara pesantren yang akan berdiri dengan masyarakat sekitar, yang selalu dimenangkan oleh pihak pesantren, sehingga pesantren diterima untuk hidup dimasyarakat dan kemudian menjadi panutan (Dhofir, 1983).

Tadris, Volume 13/ No. 2/ Tahun 2019 | 64 
Senada dengan Nafi (2007) yang mengemukakan bahwa pesantren mengemban beberapa peran, utamanya sebagai lembaga pendidikan Islam yang sekaligus juga memainkan peran sebagai lembaga bimbingan keagamaan, keilmuan, pelatihan, pengembangan masyarakat, dan sekaligus menjadi simpul budaya, maka itulah pondok pesantren, biasanya peran-peran itu tidak langsung terbentuk, melainkan melewati tahap demi tahap. Setelah sukses sebagai lembaga pendidikan pesantren bisa pula menjadi lembaga keilmuan, kepelatihan, dan pemberdayaan masyarakat. Keberhasilan membangun integrasi dengan masyarakat barulah memberinya mandat sebagai lembaga bimbingan keagamaan. Sebagai lembaga pendidikan yang berumur sangat tua ini, pesantren dikenal sebagai media pendidikan yang menampung seluruh jenis strata masyarakat. Lebih jauh pesantren membuat lembaga pendidikan umum yang didalamnya tidak hanya mengajarkan agama saja. Sehingga hal tersebut menjadi pemicu lahirnya jenis pendidikan formal, madrasah dan sekolah umum di pesantren dengan tujuan untuk memenuhi ketentuan pembangunan dan kemajuan ilmu dan teknologi atau dengan kata lain untuk memenuhi tuntutan zamannya. Kedua jenis pendidikan ini ternyata menjadi jembatan bagi pesantren yang menghubungkannya dengan sistem pendidikan nasional, dan sebaliknya kedua jenis pendidikan formal juga mendapat penyempurnaan dari jenis pendidikan non formal, yaitu "pesantren", terutama mengenai moral yang tidak dapat didikkan secara formal di madrasah dan sekolah umum tersebut. Dengan demikian terjadi simbiosis mutualistis kurikulum antar ke tiga jenis pendidikan tersebut; yaitu pesantren, madrasah dan sekolah umum.

Pesantren pada umumnya bersifat mandiri, tidak tergantung kepada pemerintah atau kekuasaan yang ada. Karena sifat mandirinya itu, pesantren bisa memegang teguh kemurnianlembaga pendidikan Islam. Karena itu, pesantren tidak mudah disusupi oleh ajaranajaran yang tidak sesuai dengan ajaran Islam.Sekalipun belakangan issu terorisme dienduskan dari kalangan pesantren, sebenarnya faham semacam itu tidak pernah diajarkan di lembaga pesantren. Pendidikan pondok pesantren yang merupakan bagian dari Sistem Pendidikan Nasional memiliki 3 unsur utama yaitu: 1) Kyai sebagai pendidik sekaligus pemilik pondok dan para santri; 2) Kurikulum pondok pesantren; dan 3) Sarana peribadatan dan pendidikan, seperti masjid, rumah kyai, dan pondok, serta sebagian madrasah dan bengkel-bengkel kerja keterampilan. Kegiatannya terangkum dalam "Tri Dharma Pondok pesantren" yaitu: 1) Keimanan dan ketaqwaan kepada Allah SWT; 2) Pengembangan keilmuan yang bermanfaat; dan 3) Pengabdian kepada agama, masyarakat, dan negara.

Kalangan pesantren menempatkan ilmu bukan sebagai ideologi yang tertutup. Terlebih sebagai lembaga pendidikan, ilmu-ilmu pesantren dengan meminjam kategorisasinyabersifat 
terbuka dan dalam memperlakukan sebuah fakta berangkat dari fakta sosial. Disamping itu, pesantren adalah dipengaruhi pendidikan dari Makkah. Sepulangnya ke kampong halaman, para pelajar yang mendapat gelar "haji" ini mengembangkan pendidikan di tanah air yang bentuk kelembagaannya kemudian disebut "pesantren" atau "pondok pesantren" Dalam analisi penulis Bahkan adanya kehadiran pesantren dengan santri yang banyak dapat menghidupkan ekonomi masyarakat sehingga dapat memakmurkan masyarakat sekitar.

Dari pemaparan diatas dapat penulis analisis bahwa Pesantren-ulama/kiai dan santri biasanya memiliki hubungan yang cukup erat dengan masyarakat sekelilingnya. Bahkan tradisi yang berlaku didunia pesantren ini pun berlaku dalam dunia luar pesantren. Hal ini dapat terjadi dengan undangan dari masyarakat kepada kiai untuk menghadiri acara tertentu atau dari para alumni pesantren yang menyebar kedaerah-daerah untuk menyebarkan ilmu yang telah didapatkannya dipesantren. Seperti pada peringatan maulid Nabi, Nuzul alQur'an, walimah al-ursy, pengajian dan lain sebagainya. Tradisi pesantren merupakan krangka sistem pendidikan Islam tradisonal di jawa dan Madura, yang dalam perjalan sejarahnya telah menjadi obyek peneliti para sarjana yang mempelajari Islam di Indonesia, beberapa kumpulan karangan tentang pesantren yang ditulis oleh sekelompok intelektual Islam Indonesia turut membantu menambah pengetahuan kita tentang pesantren.

Dari saling berkelindannya kiai pesantren-santri ini tentunya memiliki pengaruh besar dalam masyarakat. Seorang santri yang baru ke pesantren satu tahun saja, ketika pulang, dikampungnya akan diperlakkukan layaknya seorang kiai oleh masyarakat dii tempat ia tinggal. Maka tak jarang masyarakat karena kecintaan mereka terhadap pesantren banyak memberikan shadaqah, infaq, waqaf dan amal jariyah lainnya dengan ikhlas untuk perkembangan pesantren.

Selanjutnya, Proses pengembangan dunia pendidikan pesantren yang selain menjadi tanggung jawab internal pesantren, juga harus didukung oleh pemerintah secara serius sebagai proses pembangunan lembaga pendidikan terutama pendidikan islam di Negara yang mayoritas penduduknya beragama islam. Meningkatkan dan mengembangkan peran serta pesantren dalam proses pembangunan merupakan langkah strategis dalam membangun mewujudkan tujuan pembangunan nasional terutama sektor pendidikan. Terlebih, dalam kondisi yang tengah mengalami krisis (degradasi) moral. Pesantren sebagai lembaga pendidikan yang membentuk dan mengembangkan nilai-nilai moral, dengan basic agama harus menjadi pelopor sekaligus inspirator pembangunan moralbangsa. Sehingga, pembangunan tidak menjadi hampa melainkan lebih bernilai dan bermakna. 
Pondok pesantren yang memiliki kreteria tertentu dianggap telah mapan, didukung oleh persyaratan yang cukup mapan, seperti bangunan, tanah, guru yang berkompeten, muridmurid yang banyak serta tersedianya tenaga administrasi. Pondok pesantren yang seperti inilah yang dianggap layak untuk mengakomodasi sistem pendidikan formal atau elemen pendidikan lainnya yang berasal dari luar. Sebaliknya, pondok pesantren yang tidak memiliki dan memenuhi kriteria di atas tentu saja tidak bisa memaksakan kehendak untuk mengadopsi sistem pendidikan dari luar (Mahfuddin, 2006).

Beberapa tahun yang lalu, ada fenomena menarik dalam dunia pendidikan di Indonesia yakni munculnya penyelenggaraan sekolah bermutu yang sering disebut dengan boarding school. Nama lain dari istilah boarding school adalah sekolah berasrama. Para murid mengikuti pendidikan reguler dari pagi hingga siang di sekolah, kemudian dilanjutkan dengan pendidikan agama atau pendidikan nilai-nilai khusus di malam hari. Selama 24 jam anak didik berada di bawah didikan dan pengawasan para guru pembimbing. Tanpa disadari, sesungguhnya sekolahsekolah itu merusaha meniru pola pendidikan pesantren, yang ternyata lulusan pesantren tidak kalah mutunya dengan lulusan sekolah-sekolah umum. Di sisi lain, sistem pesantren ternyata lebih unggul dalam membentuk kepribadian santri, hal ini dibuktikan hingga sekarang belum ditemukan kasus santri tawuran antar santri atau pesantren, demikian juga dengan sekolah-sekolah umum. Sementara itu, tawuran antar pelajar pada sekolah-sekolah umum seakan-akan menjadi tontonan masyarakat yang hampir setiap waktu terjadi tawuran (Tempo.Co : 2012). Kekuatan pesantren dalam membentuk kepribadian santri sebagaimana telah dikemukakan, tidak terlepas dari system boarding school yang telah lama diterapkan dalam pendidikian pesantren.

\section{Pesanten Sebagai Pencetak Ulama}

Eksistensi pondok pesantren dalam menyikapi perkembangan zaman, tentunya memiliki komitmen untuk tetap menyuguhkan pola pendidikan yang mampu melahirkan sumber daya manusia (SDM) yang handal. Kekuatan otak (berpikir), hati (keimanan) dan tangan (keterampilan), merupakan modal utama untuk membentuk pribadi santri yang mampu menyeimbangi perkembangan zaman. Sudah tidak diragukan lagi bahwa pesantren memiliki kontribusi nyata dalam pembangunan pendidikan islam. Apalagi dilihat secara historis, pesantren memiliki pengalaman yang luar biasa dalam membina dan mengembangkan masyarakat terutama masyarakat islam. Bahkan, pesantren mampu meningkatkan perannya secara mandiri dengan menggali potensi yang dimiliki masyarakat disekelilingnya. Berbagai kegiatan keterampilan dalam bentuk pelatihan atau workshop yang lebih memperdalam ilmu 
pengetahuan dan keterampilan kerja adalah upaya untuk menambah wawasan santri di bidang ilmu sosial, budaya dan ilmu praktis, merupakan salah satu terobosan konkret untuk mempersiapkan individu santri di lingkungan masyarakat.

Pada masa orde lama dan orde baru, meskipun mendapat tekanan dari pihak pemerintah, pesantren tetap mampu menelorkan orang-orang hebat yg menjadi orang- orang penting di negara kita seperti KH Wahid Hasyim, M Nastir, Buya Hamka, Mukti Ali, KH Saifuddin Zuhri dll. Mulai tahun 1970-an dan diakhir tumbangnya orde baru yang dimana ekonomi Indonesia mulai ambruk, pesantren tampak kembali dengan supremasinya karena adanya program-program baru yang digulirkan oleh pemerintah yaitu ekonomi kerakyatan. Pihak pemerintah berupaya menggandeng pesantren sebagai mitra dalam pengentasan kemiskinan dan mengembangkan ekonomi kerakyatan (PPIM IAIN Jakarta: 1997-1998). Dijadikannya pesantren sebagai agen pembangunan yang berorientasi kerakyatan karena pesantren dianggap satu-satunya lembaga yang eksis dan dipercaya untuk penyaluran danadana ekonomi kerakyatan serta memiliki akar bawah yang sangat kuat dan sikap mentalitas yang bisa dipertanggung jawabkan. Tawaran ini ditanggapi dengan serius dan diterima oleh pesantren (Kuntowijoyo, 1993). sehingga tidak heran saat itu banyak pesantren yang mendapat hadiah kalpataru dari pemerintah Suharto, karena peran pesantren dalam pengembangan ekonomi umat juga pesantren menjadi mitra ekonomi kerakyatan pemerintah.

Hasyim (2015) menyajikan bukti bahwa sejak dulu pesantren dikenal sebagai tempat pengkaderan ulama, tempat pengajaran ilmu agama dan memelihara tradisi Islam. Fungsi ini terus berkembang akibat tuntutan pembangunan nasional yang mengharuskan pesantren terlibat di dalamnya. Sekarang pertumbuhan pesantren sangat pesat, menjamurnya pesantren dengan spesialisasi dan ragam kajian dari tradisional hingga modern membawa dampak positif bagi pendidikan nasional secara umum dan pendidikan Islam khususnya. Kehadiran pesantren bukan hanya membantu pemerintah dalam rangka mencerdaskan bangsa yang tidak mungkin terjamah secara keseluruhan, namun lebih dari itu pesantren menawarkan jenis pendidikan alternatif bagi pengembangan pendidikan nasional.

Analisis penulis menanggapi Dalam menghadapi tantangan yang semakin kompleks dilingkungan masyarakat, maka pondok pesantren harus berani tampil dan mengembangkan dirinya sebagai pusat keunggulan. Pondok pesantren tidak hanya mendidik santri agar memiliki ketangguhan jiwa (taqwimu al-nafs), jalan hidup yang lurus, budi pekerti yang mulia, tetapi juga santri yang dibekali dengan berbagai disiplin ilmu keterampilan lainnya, guna dapat diwujudkan dan mengembangkan segenap kualitas yang dimilikinya. 
Karena itulah akhir-akhir ini pondok pesantren mempunyai kecenderungan baru dalam rangka renovasi terhadap sistem yang selama ini dipergunakan, yaitu: (1) Mulai akrab dengan metodologi ilmiah moderen. (2) Semakin berorientasi pada pendidikan dan fungsional, artinya terbuka atas perkembangan diluar dirinya. (3) Diversifikasi program dan kegiatan makin terbuka dan ketergantungannya pun dengan kiai. (4) Dapat berfungsi sebagai pusat pengembangan masyarakat.

Berdasarkan tujuan pesantren adalah membina warga negara agar berkepribadian muslim sesuai dengan ajaran-ajaran agama Islam dan menanamkan rasa keagamaan tersebut pada semua segi kehidupannya serta menjadikannya sebagai orang yang berguna bagi agama, masyarakat dan negara (Qamar, 2002).

Untuk mencapai tujuan di atas, para santri harus dibekali sejumlah nilai keislaman yang dipadukan dengan keterampilan. Paling tidak tiga hal yang mesti digarap oleh pondok pesantren yang sesuai dengan jati dirinya. pertama, pesantren sebagai lembaga pendidikan pengkaderan ulama. Namun demikian, tuntutan modernisasi dan perkembangan IPTEK mengharuskan ulama memiliki kemampuan lebih, kapasitas intelektual yang memadai, wawasan, akses pengetahuan dan informasi yang cukup serta responsive terhadap perkembangan dan perubahan. Kedua, pesantren sebagai lembaga pengembangan ilmu pengetahuan khusus agama Islam. Pada tatanan ini, pesantren masih dianggap lemah dalam penguasaan ilmu dan metodologi. Pesantren hanya mengajarkan ilmu agama dalam arti transfer of knowledge. Karena pesantren harus jelas memiliki potensi sebagai "lahan" pengembangan ilmu agama. Ketiga, dunia pesantren harus mampu menempatkan dirinya sebagai transformasi, motivator, dan inovator.

Dalam menghadapi era globalisasi dan perkembangan IPTEK, Zaini (1994) menawarkan lima jurus yang harus dilakukan pesantren, yaitu: Pertama, Pesantren sebagai lembaga dakwah, harus mampu menempatkan dirinya sebagai transformator, motivator dan invator masyarakat. Kedua, Pesantren sebagai lembaga pengkaderan ulama' dituntut agar dapat menciptakan para lulusannya mempunyai kemampuan analisis dan antisipatif. Ketiga, Sebagai lembaga ilmu pengetahuan, pesantren dituntut agar secara bertahap dan sistematis dapat mengembalikan Islam sebagai agen ilmu pengetahuan, sebagaimana zaman sebelum agen keilmuan dipegang oleh bangsa Barat. Keempat, Pesantren sebagai lembaga pengembangan masyarakat, khususnya masyarakat industri. Kelima, Para santrinya dituntut untuk semakin meningkatkan kualitas iman dan taqwanya dan juga dituntut agar dapat menjalankan peran sebagai khalifah fil ardhi. 
Bersamaan dengan mainstream perkembangan dunia (globalisasi) dan perkembangan IPTEK pesantren dihadapkan pada beberapa perubahan sosial budaya yang tak terelakkan. Untuk itu, pesantren hendaknya melakukan upaya-upaya rekonstruksi dengan: Memperbaiki metode pendidikan pesantren, Memperbaiki kurikulum pendidikan pesantren, Memperbaiki manajemen pendidikan pesantren, dan Memperbaiki sarana dan prasaran (Zaini, 1994).

Karena itu diharapkan pesantren harus semakin adaptif terhadap perkembangan kamajuan zaman. Atas dasar itu peluang pesantrean sebagai lembaga Pendidikan Islam yang akan menciptakan manusia seutuhnya akan semakin terbuka (Daulay, 2004).

\section{PENUTUP}

\section{Kesimpulan}

Pondok pesantren ditinjau dari segi bahasa, kata pondok berasal dari bahasa Arab funduq yang artinya hotel. Dalam perspektif masyarakat Indonesia diartikan sebagai tempat berlangsungya suatu pendidikan Agama Islam yang telah melembaga sejak zaman dahulu. Jadi, pada hakikatnya pondok pesantren merupakan lembaga pendidikan Islam yang memberikan pengajaran, pendidikan, pembinaan dan menyebarkan agama Islam. Metode utama sistem pengajarannya adalah sistem bandongan atau weton dan sorogan, andongan atau weton dan sorogan.

Unsur-unsur pondok pesantren terdiri dari kiai sebagai tokoh sentral, santri, masjid, kitab kuning dan asrama. Adapun klasifikasi pondok pesantren terdiri dari pesantren salafi dan pesantren khalafi. Untuk santri sendiri ada yang dikenal santri mukim dan santri kalong. Tujuan pendidikan pesantren adalah pada pengamalan terhadap ilmu yang telah diperoleh yang disebut dengan ilmu bermanfaat (ilm năfi) dalam rangka membina kepribadian Islami, yaitu kepribadian yang beriman dan bertakwa kepada Allah SWT, berakhlak mulia, bermanfaat dan berkhidmat kepada masyarakat dengan menjadi pelayan umat (khadim alummah) dalam rangka meninggikan kalimat Allah dan kejayaan kaum muslimin.

Fungsi utama pesantren adalah sebagai lembaga pendidikan islam yang bertujuan mencetak muslim agar memiliki dan menguasai ilmu-ilmu agama secara mendalam serta menghayati dan mengamalkannya dengan ikhlas semata-mata ditujukan untuk pengabdiannya kepada Allah. Selain menjalankan peran utamanya sebagai lembaga pendidikan Islam dan menyebarkan ajaran Islam, sekaligus juga memainkan peran sebagai lembaga bimbingan keagamaan, keilmuan, pelatihan, pengembangan masyarakat, dan sekaligus menjadi simpul budaya, maka itulah pondok pesantren, biasanya peran-peran itu tidak langsung terbentuk, melainkan melewati tahap demi tahap. Setelah sukses sebagai lembaga pendidikan pesantren 
bisa pula menjadi lembaga keilmuan, kepelatihan, dan pemberdayaan masyarakat. Keberhasilan membangun integrasi dengan masyarakat barulah memberinya mandat sebagai lembaga bimbingan keagamaan.

Selain menjalankan peran sebagai lembaga pendidikan islam, pesantren juga sebagai tempat yang mampu melahirkan banyak ulama'. Tidak sedikit tokoh Islam lahir dari lembaga pesantren. Bahkan Prof.Dr.Mukti Ali pernah mengatakan bahwa tidak pernah ada ulama yang lahir dari lembaga selain pesantren.

Pondok pesantren berperan dalam membentuk lulusan yang memiliki kepribadian amar ma'ruf nah̄̄ munkar di tengah-tengah masyarakat, karena amar ma'ruf nahī munkar merupakan bentuk aktualisasi ajaran Islam. Suryana (2006) mencatat bahwa amar ma'ruf nahī munkar merupakan bentuk aktualisasi ajaran Islam di tengah masyarakat dengan cara menegakkan kebenaran dan membenci keburukan dan kemungkaran yang ada di tengah masyarakat. Amar ma'ruf adalah keberpihakan seorang muslim terhadap kebenaran, kendatipun kebenaran itu merugikan dirinya. Demikian pula nahi munkar atau membenci kemunkaran harus selalu ditampilkan kendatipun keburukan itu akan menguntungkan dirinya.

\section{DAFTAR RUJUKAN}

Abubakar, I. 2018. Strengthening Core Values Pesantren as a Local Wisdom of Islamic Higher Education Through Ma'had Jami 'ah. IOP Conference Series : Earth and Environmental Science, 1-7.

Adhim, Masduki dan Abd, 2004. Sinergi Madrasah dan Pondok Pesantren. Jakarta: Depag RI.

al-Djamaly, Mohammad Fadhil. 1967. Tarbiyah al-Insan al-Jadid, Tunisia: Matba'ah alIttihad al-‘Am al-Tunisiyah al-Syughli.

al-Syaebani, Omar Muhammad al-Touny. 1979. Falsafah Pendidikan Islam, terj. Hasan Langgulung, Jakarta: Bulan Bintang.

Alhamuddin. 2005. Pendidikan Islam Modern ala Trimurti Pondok Modern Darussalam Gontor. AtTa'dib, 3(2), 203-231.

Arifin. 1993. Filsafat Pendidikan Islam. Jakarta: Bumi Aksara. 
Basrowi dan suwandi. 2008. Memahami penelitian kualitatif. Jakarta: rineka cipta.

Daulay, Haidar Putra. 2004 Pendidikan Islam, Dalam Sistem Pendidikan Nasional. Jakarta: Prenada Media.

Dhofir, Zamakhsyari. 1983. Tradisi Pesantren; Studi tentang Pandangan Hidup Kiyai. Jakarta: LP3ES.

Dian Nafi dkk. 2007. Praksis Pembelajaran Pesantren. Yogyakarta: LKis Pelangi Aksara.

Dhofier, Z. 1994. Tradisi Pesantren. Yogyakarta: LP3ES.

Engku, I., \& Zubaidah, S. 2014. Sejarah Pendidikan Islami. Bandung: Remaja Rosdakarya.

Fauziyah, E. 2014. Pembentukan Kepribadian Santri Dalam Sistem Pondok Pesantren Salafi Miftahul Huda Cihideung Bogor. Jakarta: Universitas Islam Negeri (UIN) Syarif Hidayatullah.

Haryanto, R. 2017. Pemberdayaan Santri Podok Pesantren Musthafawiyah di Era Globalisasi (Studi Kasus Pondok Pesantren Musthafawiyah). Al-Ishlah : Jurnal Pendidikan, 9 (2), 16-32.

Mastuhu. 1994. Dinamika Sistem Pendidikan Pesantren. Jakarta, INIS.

Moleong, Lexy J. 2014. Metodologi Penelitian Kualitatif. Bandung: Remaja Rosdakarya.

Mujahidin, Endin. 2004. Pesantren Kilat. Jakarta: Pustaka Al Kautsar, 2004.

Muhtaron. 2002. Dinamika Pesantren dan Madrasah. Yogyakarta: Pustaka Pelajar.

Nata, Abudin. 1997. Filsafat Pendidikan Islam 1. Jakarta: Logos Wacana Ilmu. 
Noor, Mahpuddin. 2006. Potret Dunia Pesantren. Bandung: Humaniora.

Qamar, Mujamil. 2002. Pesantren, Jakarta: Gelora Aksara Pratama.

Ridhwan, Nurdin, A., \& Samad, S. A. A. 2018. Dynamics of Islamic Education in The Land of Bugis : Growth, Development and Typology Pesantren in Bone. IOP Conference Series : Earth and Environmental Science, 1-8.

Rizal, A. S. 2011. Transformasi Corak Edukasi Dalam Sistem Pendidikan Pesantren, Dari Pola Tradisi Ke Pola Modern. Jurnal Pendidikan Agama Islam - Ta’lim, 9 (2).

Setiawan, E. 2012. Eksistensi Budaya Patron Klien Dalam Pesantren : Studi Hubungan Antara Kiai dan Santri, 13(2), 137-152.

Tamin AR, Z. 2015. Pesantren dan Politik (Siergi Pendidikan Pesantren dan Kepemimpinan dalam Pandangan KH. M. Hasyim Asy'ari). Jurnal Pendidikan Agama Islam, 3(2).

Tauhid, Abu. 1990. Beberapa Aspek Pendidikan Islam. Yogyakarta: Sekretariat Jurusan Fakultas Tarbiyah.

Zaini, A. Wahid. 1994. Dunia Pemikiran Kaum Santri, Yogyakarta: LKPSM. Zamakhsyari Dhofier. 1994.Tradisi Pesantren. Jakarta: LP3ES.

Zuhairini, dkk. 1995. Filsafat Pendidikan Islam. Jakarta: Bumi Aksara. 